\title{
AUDIOVISUAL: PRESENTE NA HISTÓRIA, PRESENTE DA HISTÓRIA
}

\section{AUDIOVISUAL: PRESENT IN HISTORY, HISTORY'S PRESENT}

Bianca Melyna Filgueira*

HAGEMEYER, Rafael Rosa. História \& audiovisual. Belo Horizonte: Autêntica, 2012. 159 p.

Em entrevista a Silvia Maria Fávero Arend e Fábio Macedo, Henry Rousso afirmou que história do tempo presente é aquela em que o historiador investiga um tempo que é o seu próprio tempo, partindo de uma memória que pode ser a sua própria. Rousso assinalou, ainda, que, para o historiador desse tempo, não saber ler as imagens é como não saber ler os arquivos com documentação escrita. ${ }^{1} \mathrm{O}$ percurso do audiovisual e sua relação com a história, na forma proposta por Rafael Rosa Hagemeyer em História \& Audiovisual, de saída, provoca uma reflexão nesse sentido. A escolha por abarcar as distintas faces do audiovisual - televisão, cinema, vídeo e videogame - localizam essa obra num tempo mediado como nunca antes por esses produtos culturais.

Atualmente professor do curso de História da Universidade do Estado de Santa Catarina - UDESC, Hagemeyer coordena o Laboratório de Imagem e Som - LIS, onde História \& Audiovisual foi gestado. A observação das dificuldades enfrentadas pelos estudantes, ao tentarem produzir conhecimento histórico a partir de registros audiovisuais, foi, segundo o autor, o input desse livro.

Debruçando-se sobre temas como memória política e música popular, iconografia da Guerra Civil Espanhola e relações entre cinema, ideologia e representações da classe operária nos anos 1970, o autor demonstra uma preocupação tributária de uma história que pretende analisar seus produtos

\footnotetext{
* Mestre em História Cultural pela Universidade Federal de Santa Catarina (UFSC).
}

E-mail: bi_hst@yahoo.com.br 
culturais dentro de um contexto, notadamente o político. Em História \& Audiovisual esse último componente também aparece, assinalando principalmente os usos ideológicos do audiovisual e como a interdição ou o acesso do historiador a esses produtos culturais tem influído na construção do conhecimento histórico.

O livro é organizado e dividido em três capítulos que se entrecruzam todo o tempo. No primeiro, Da legitimidade do audiovisual como fonte de conhecimento, o autor reflete a partir de uma perspectiva talvez um tanto filosófica sobre como as desconfianças em relação aos registros audiovisuais como fonte e objeto de pesquisa dificultaram seu estabelecimento e legitimação na construção do conhecimento no campo das ciências humanas, notadamente a história. Além disso, discute sobre as questões de método que envolvem o tratamento desses registros, realçando três perspectivas: semiológica, formalista e contextualista.

A primeira constituiu-se a partir da teoria da linguagem formulada por Ferdinand Saussure, que procurava entender os processos de significação por meio da estrutura do signo. Seus elementos constituintes, significante e significado, seriam simplificadamente, análogos a som e imagem. Já a perspectiva formalista levaria em conta as formas empregadas para se chegar ao contexto, analisando enquadramentos, luminosidade, volume etc. Por fim, os contextualistas defendem uma interpretação sociológica da arte, partindo do contexto para se chegar à forma. Essas teorias foram inicialmente postuladas no âmbito da história da arte, o que faz com que o autor se questione se elas podem ser estendidas ao estudo de outros registros imagéticos, como o cinema e a televisão.

Aliás, a preocupação de Hagemeyer com a análise da programação televisiva, com a patrimonialização desses registros e com a garantia de acesso aos historiadores é evidente e cabível. Esse é um dos aspectos que remete ao que dizíamos no início, sobre o lugar que essas reflexões ocupam no tempo em que foram concebidas.

No segundo capítulo, A história dos audiovisuais: desenvolvimento de técnicas e linguagens, o autor propõe uma trajetória não linear do registro imagético. Com amplo recorte, delineia as transformações técnicas pelas quais passaram os registros imagéticos, as artes plásticas, a fotografia, o cinema e a televisão de maneira descontínua. É nesse capítulo que analisa especificamente o percurso da imagem em movimento em diferentes suportes: primeiro, o cinema, depois, a televisão e, por último, o vídeo e o videogame.

Seguindo a tendência de uma história social do cinema, Hagemeyer procura refletir sobre esse produto cultural a partir de três aspectos que o caracterizam e que se determinam mutuamente: o aspecto técnico, o comercial e o comunicacional. Mas, novamente, é em relação à televisão que as maiores 
inquietações aparecem, assim como os mais interessantes questionamentos: levando em conta a natureza descontínua e fragmentada das imagens e da programação televisiva, qual seria o impacto dessa aleatoriedade sobre a consciência humana? Como o historiador deve enfrentar o desafio da análise da programação televisiva? Como enfrentar a questão da recepção?

No que se refere ao vídeo e ao videogame, Hagemeyer concentra-se em refletir sobre a existência de uma linguagem própria, que não é exatamente a mesma do cinema e da televisão. E encerra o capítulo chamando a atenção para um dos aspectos mais enfatizados no que diz respeito aos games: sua narratividade.

No terceiro e último capítulo, sob o título A história dos meios audiovisuais: entre a veracidade do registro e o poder evocativo das simulações, Hagemeyer procura discutir questões que relacionam a linguagem audiovisual com o discurso historiográfico e com a própria narrativa da história. Para tanto, debate longamente acerca da dicotomia ficção/documentário e o "efeito de verdade", enfatizando que os processos de edição pelo qual se organiza o fluxo de imagens de um documentário determinam uma forma de narrativa que sempre constituirá um argumento cinematográfico, podendo produzir um efeito de verdade, mas de maneira nenhuma constituindo verdades absolutas. Da mesma forma, problematiza a questão das reconstituições históricas no cinema, na medida em que esses filmes subtraem, assim, sua vocação maior que é a de testemunhar sua própria época.

Nesse capítulo, o autor mais uma vez deixa entrever uma preocupação como homem e historiador de seu tempo, refletindo sobre o uso de registros audiovisuais como recursos didático-pedagógicos nas escolas e sobre como uma educação audiovisual deve ser parte do processo de sensibilização e construção de significados sócio-históricos de futuros cidadãos. A busca por esse entendimento é, de fato, o que justifica todas as contendas epistemológicas assinaladas pelo autor.

Ao se discutir história e audiovisual parece inevitável o enfrentamento com determinados conceitos carregados de polissemia no campo das ciências humanas: cultura, realidade, representação etc. Tais conceitos, em dados momentos, foram o epicentro das disputas no campo da epistemologia da história, evidentemente porque essas disputas são, também, políticas. Hagemeyer explora alguns desses conceitos e informa o leitor sobre as tensões que gravitam em torno deles. Porém, ao fazer isso notadamente no último capítulo, quando os conceitos aparecem nos anteriores quase sempre são acompanhados de umas aspas inquietantes: ficamos em dúvida se, com elas, quer o autor chamar a atenção exatamente para essa polissemia ou se o que pretende é indicar a dificuldade dos historiadores, de modo geral, de trabalharem com categorias de análise. 
Ainda na seara dos conceitos, em História \& Audiovisual deparamo-nos com algumas expressões e definições que somente o leitor especializado sabe se tratarem de postulados de outros autores (como o conceito de "transparência", próprio de Ismail Xavier), sem maiores comentários ou referências por parte do autor. Isso suscita uma dúvida sobre o próprio caráter da obra: se foi escrita a partir da observação das dificuldades dos estudantes ao relacionarem conhecimento histórico e audiovisual, destinar-se-ia a esses estudantes?

Falar sobre história e audiovisual sem recorrer ao uso de nenhuma imagem foi uma escolha metodológica de Hagemeyer. Desse modo, o autor procura chamar a atenção para os problemas decorrentes da transcodificação de uma narrativa imagética em uma narrativa escrita, mas reflete também uma tendência de, nessa obra, separar o que é papel do teórico de cinema e do historiador. Segundo ele, caberia ao primeiro analisar elementos como composição e enquadramento e, ao segundo, observar tudo aquilo o que é enquadrado e que pode fornecer pistas sobre como uma sociedade tomou forma historicamente. Essas imputações não deixam de ser perturbadoras, já que a observância de aspectos técnicos e estéticos pelo historiador - evidentemente dentro de certos limites, como o próprio Hagemeyer não deixa de assinalar em outro momento -, muitas vezes pode levá-lo a pistas valiosas sobre, por exemplo, o contexto de produção de determinado registro audiovisual, às quais não se seria possível chegar apenas observando-se as representações presentes no registro.

Mas essas poucas ressalvas assinaladas jamais comprometeriam o valor desse livro que, mais do que uma reflexão sobre o tratamento do audiovisual, evoca questionamentos sobre o próprio fazer do historiador, que muitas vezes se encerra dentro dos muros acadêmicos e se dedica a discussões teóricas que perdem de vista o que existe na outra margem de seu métier: o ensino da história, o estudante, o futuro cidadão. O repertório imagético que esses cidadãos vão acumulando ao longo de suas vidas muitas vezes completam os sentidos construídos pela educação "formal", ressignificam, ou, como bem assinala Hagemeyer, vulgarizam o conhecimento histórico. Essa vulgarização, antes de horrorizar os historiadores, deve ser entendida como uma etapa necessária e intrínseca da construção do conhecimento.

Como se vê, o audiovisual, presente na/da história, coloca problemas que vão além da teoria e epistemologia. O livro de Rafael Rosa Hagemeyer é, para aqueles que desejam iniciar uma reflexão sobre o presente... Um presente. 


\section{NOTAS}

1 AREND, Silvia Maria Fávero; MACEDO, Fábio. Sobre a história do tempo presente: entrevista com o historiador Henry Rousso. Tempo e Argumento. Florianópolis, v. 1, n. 1, p. 201-216, jan./jun. 2009.

Resenha recebida em junho de 2012. Aceita em agosto de 2012. 